\title{
Discontinuation of Immunosuppressive Therapy in Patients With Neuromyelitis Optica Spectrum Disorder With Aquaporin-4 Antibodies
}

Su-Hyun Kim, MD, PhD, Hyunmin Jang, RN, Na Young Park, RN, Yeseul Kim, MSc, So-Yeon Kim, BSc, Min Young Lee, MD, Jae-Won Hyun, MD, PhD, and Ho Jin Kim, MD, PhD

Neurol Neuroimmunol Neuroinflamm 2021;8:e947. doi:10.1212/NXI.0000000000000947

\section{Abstract}

\section{Objective}

To evaluate the outcomes of immunosuppressive therapy (IST) discontinuation in patients with neuromyelitis optica spectrum disorder (NMOSD) after a sustained remission period.

\section{Methods}

We retrospectively reviewed the medical records of 17 patients with antiaquaporin-4 antibodypositive NMOSD who discontinued IST after a relapse-free period of $\geq 3$ years.

\section{Results}

IST was discontinued at a median age of 40 years (interquartile range [IQR], 32-51) after a median relapse-free period of 62 months (IQR, 52-73). Among the 17 enrolled patients, 14 (82\%) relapsed at a median interval of 6 months (IQR, 4-34) after IST discontinuation, 3 (18\%) of whom experienced severe attacks; notably, all 3 of these patients had a history of severe attack before IST. These 3 patients received steroids, followed by plasma exchange for acute treatment, but 2 exhibited poor recovery and significant disability worsening at 6 months after relapse.

\section{Conclusions}

IST discontinuation may increase the risk of relapse in seropositive patients with NMOSD even after 5 years of remission. Given the potentially devastating consequence of a single attack of NMOSD, caution is advised with IST discontinuation, particularly in patients with severe attack before IST.
Correspondence

Dr. Kim

hojinkim@ncc.re.kr 


\section{Glossary}

AQP4 = aquaporin-4; AZA = azathioprine; DMT = disease-modifying therapies; EDSS = Expanded Disability Status Scale; $\mathbf{I Q R}=$ interquartile range; IST = immunosuppressive therapy; $M M F=$ mycophenolate mofetil; NMOSD = neuromyelitis optica spectrum disorder.

Neuromyelitis optica spectrum disorder (NMOSD) is a rare and severe inflammatory disorder of the CNS associated with aquaporin-4 (AQP4) antibodies. ${ }^{1}$ Because of the high morbidity associated with NMOSD relapse, early initiation of immunosuppressive therapy is recommended. ${ }^{2}$ Rituximab, mycophenolate mofetil (MMF), and azathioprine (AZA) are the most commonly prescribed therapeutic agents for preventing relapse in NMOSD. Although these agents are generally well-tolerated, the long-term use of these drugs may lead to an increased risk of opportunistic infections, particularly in elderly patients, resulting in increased economic burden. However, there is no current consensus regarding the optimum duration of immunosuppressive therapy (IST), and a common clinical dilemma is the feasibility of treatment withdrawal in patients who have achieved a sustained period of remission. Here, we aimed to evaluate the outcomes of IST discontinuation in patients with NMOSD with a sustained remission period before discontinuation.

\section{Methods}

\section{Participants and Data Collection}

We retrospectively evaluated medical records of $252 \mathrm{pa}-$ tients with NMOSD, according to the 2015 NMOSD criteria, ${ }^{1}$ who were positive for AQP4 antibodies and underwent continuous IST with MMF, AZA, or rituximab for $\geq 3$ years at the National Cancer Center, Korea, between May 2005 and March 2020. Of these patients, we identified 18 patients who discontinued IST after $\geq 3$ years of relapse-free period on IST. One patient was lost to follow-up and was thus excluded. Finally, we included 17 patients in this study. The study was approved by the Institutional Review Board of the National Cancer Center, Korea. Collected data included patient demographics, treatment history, relapse history, and disabilities (Expanded Disability Status Scale [EDSS]). A severe relapse was defined as an EDSS score of $\geq 6.0$, or as new worsening of visual acuity of $\leq 0.1$ points at the nadir of the attack.

\section{Treatment Protocols}

The maintenance AZA dose was $2-3 \mathrm{mg} / \mathrm{kg} / \mathrm{d}$, and the MMF dose was 1,500-2,000 mg/d. Rituximab was administered based on the frequency of memory B cells in peripheral blood according to our previously published protocol. ${ }^{3}$

\section{Laboratory Testing}

Blood samples were obtained during the follow-up once per year at the clinic. AQP4 antibodies were measured using an inhouse live cell-based assay. ${ }^{4}$

\section{Data Availability}

The data sets generated during and/or analyzed during the current study are available from the corresponding author on reasonable request.

\section{Results}

The characteristics of the 17 patients are presented in table. IST was discontinued after a median relapse-free period of 62 months (interquartile range [IQR], 48-73 months). Reasons for IST discontinuation included the patient's decision $(\mathrm{n}=8$, $47 \%)$, provider advice $(n=8,47 \%)$, and preparing for pregnancy $(n=1,6 \%)$.

Fourteen patients $(82 \%)$ experienced a relapse at a median interval of 6 months (IQR, 4-34 months) after discontinuation; the median interval was 4 months (IQR, 3-18 months) for patients $(n=12)$ who discontinued AZA or MMF and 85 months and 54 months for 2 patients who discontinued rituximab, respectively. Two patients who discontinued AZA and MMF maintained a stable disease course for 30 and 65 months, respectively. One patient restarted IST with MMF after 6 months of discontinuation without relapse because of concern about relapse. In our cohort, 2 patients started IST after a single attack, and both relapsed after discontinuation of IST. Eight patients (47\%) experienced severe attacks before IST, whereas $3(21 \%)$ of 14 patients experienced severe attacks after discontinuation of IST; notably, all 3 patients had a history of severe attack before IST. These 3 patients received steroids, followed by plasma exchange for acute treatment, but 2 exhibited poor recovery and EDSS worsening at 6 months after the attack.

Five (29\%) were seronegative for AQP4 antibodies at the time of discontinuation, but $4(80 \%)$ of them exhibited seroreversion (from seronegative to seropositive) after IST discontinuation (figure 1, A-C, figure e-1, links.lww.com/ NXI/A380). The remaining 11 patients were continuously seropositive for AQP4 antibodies regardless of the treatment (figure 1D, figure e-1), and 2 patients were in a remission state without IST for 65 and 30 months (figure 1, $\mathrm{E}$ and $\mathrm{F}$ ).

The 14 patients who relapsed after IST discontinuation restarted IST immediately. All but 2 had a stable disease course for a median duration of 29 months (IQR, 13-62 months) since IST was restarted. Notably, the 2 patients who attempted IST discontinuation again after 14 months and 49 months of AZA and MMF treatment relapsed again after 3 
Table Clinical and Demographic Characteristics of Patients With Neuromyelitis Optica Spectrum Disorder

\begin{tabular}{lc}
\hline Patients $(\mathbf{n}=\mathbf{1 7})$ & $33(22-39)$ \\
\hline Age at onset, $\mathbf{y}$, median (IQR) & $15(88)$ \\
\hline Sex, female, $\mathbf{n}(\%)$ & $40(32-48)$ \\
\hline Age at IST discontinuation, $\mathbf{y}$, median (IQR) & $12(6-61)$ \\
\hline $\begin{array}{l}\text { Time from disease onset to treatment, mo, } \\
\text { median (IQR) }\end{array}$ & $7(5-11)$ \\
\hline $\begin{array}{l}\text { Disease duration at IST discontinuation, } \mathbf{y}, \\
\text { median (IQR) }\end{array}$ & $3(17)$ \\
\hline IST before discontinuation, $\mathbf{n}(\%)$ & $11(65)$ \\
\hline AZA & $2(12)$ \\
\hline MMF & $1(6)$ \\
\hline Rituximab & $0.75(0.47-1.5)$ \\
\hline Mitoxantrone followed by MMF & $3(2-4)$ \\
\hline ARR before IST, median (IQR) & $3.0(1-3.5)$ \\
\hline No. of attacks before IST, median (IQR) & $2.0(1-3)$ \\
\hline EDSS at treatment initiation, median (IQR) & $2.0(1-3.5)$ \\
\hline EDSS at discontinuation, median (IQR) & \\
\hline EDSS at the last follow-up, median (IQR) & \\
\hline
\end{tabular}

Abbreviations: $\mathrm{AZA}=$ azathioprine; IQR = interquartile range; IST = immunosuppressive therapy; MMF = mycophenolate mofetil; $\mathrm{ARR}=$ annualized relapse rate; EDSS = Expanded Disability Status Scale.

and 10 months of discontinuation, respectively. There were no significant safety issues among the 17 patients during the IST period.

\section{Discussion}

In our cohort of patients with NMOSD with a median relapse-free period of 62 months before IST discontinuation, $82 \%$ of patients relapsed after a median interval of 6 months. Among them, 3 (21\%) had severe attacks, 2 of whom did not recover despite high dose steroids and plasma exchange. These findings indicate that IST discontinuation leads to an increased risk of relapse in seropositive patients with NMOSD despite a lengthy relapse-free period. Particular caution is required in patients with a history of severe attack before IST because of the risk of irreversible disability even from a single attack.

Data regarding the outcomes of IST discontinuation in patients with NMOSD are lacking. Weinfurtner et al. ${ }^{5}$ suggested that stopping rituximab treatment after disease stabilization is a viable option for some patients with NMOSD. However, among their 4 cases, 2 eventually relapsed 3 and 5 years after the last infusion of rituximab.
Likewise, in our cohort, the 2 patients previously treated with rituximab relapsed long after rituximab discontinuation. Based on a longer remission after rituximab discontinuation compared with that of AZA or MMF, we suggested that rituximab treatment before pregnancy is more advantageous for a successful pregnancy in patients with NMOSD. ${ }^{6}$ Nevertheless, long-term remission under IST does not guarantee lifelong remission after IST discontinuation.

Our study was unable to determine the factors that would predict remission maintenance after IST discontinuation because only 2 patients maintained remission after IST discontinuation. Some expert suggested that in patients with NMOSD who do not disseminate in time either clinically or radiologically, long-term therapy ( $>5$ years) may be unnecessary. ${ }^{7}$ However, 2 patients who experienced only a single attack before IST relapsed after IST discontinuation. In patients with MS, the benefits of disease-modifying therapies (DMT) may decrease with age because of diminishing inflammatory activity or having already reached significant disability, hence it may be feasible to discontinue DMT in some older patients. ${ }^{8}$ Nevertheless, unlike MS, late-onset NMOSD (age, $\geq 50$ ) are reported to be associated with worse outcomes because of high frequency of severe myelitis. ${ }^{9,10}$ Thus, the prevention of relapse by IST is still an important treatment goal in older patients with NMOSD, and IST discontinuation in older patients may not particularly more feasible. In our cohort, monitoring of AQP4 antibody serostatus was not helpful in predicting relapse after IST discontinuation. More than $60 \%$ of patients were continuously seropositive. Moreover, among 5 patients with negative seroconversion at the time of discontinuation, all except one exhibited positive seroreversion after IST discontinuation, and the time interval from seroreversion to relapse varied between patients (figure 1, A-C).

This study was limited by its retrospective and single-center design. In particular, the referral bias toward more severe cases should be taken into account. The number of enrolled patients was not large because most patients with NMOSD were unwilling to stop treatment even after a lengthy relapse-free period. Nevertheless, this is the largest case series exploring the feasibility of IST discontinuation in patients with NMOSD. Owing to the uncontrolled nature of a case series, the outcome of IST discontinuation should be interpreted with caution. However, all patients who relapsed after IST discontinuation became stable after restarting and maintaining IST. Moreover, 2 patients who restarted and stopped again relapsed several months after discontinuation. Thus, long-term remission is indeed associated with IST, not a spontaneous regression of disease activity.

In conclusion, although evaluation of the balance between risk and benefit of maintaining long-term IST should be individualized, this study advocates continuing relapse 
Figure Temporal Association of Clinical Relapse With Discontinuation of Immunosuppressive Therapy and AQP4 Antibody Status in 6 Patients With Neuromyelitis Optica Spectrum Disorder

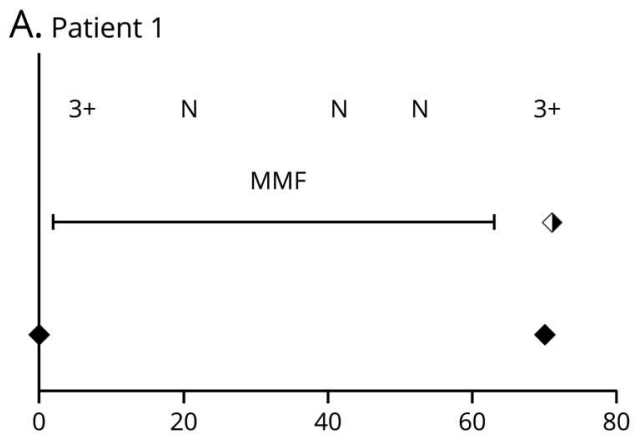

C. Patient 6

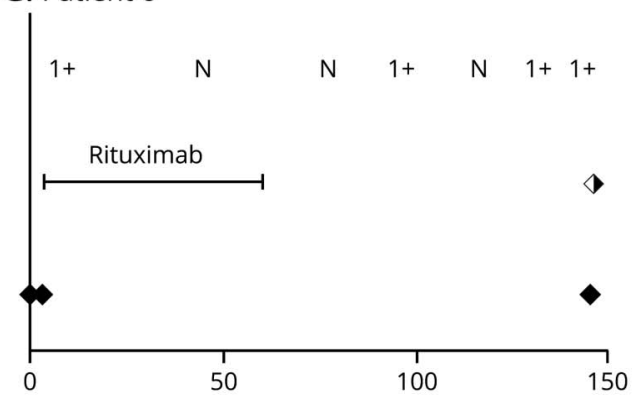

E. Patient 13

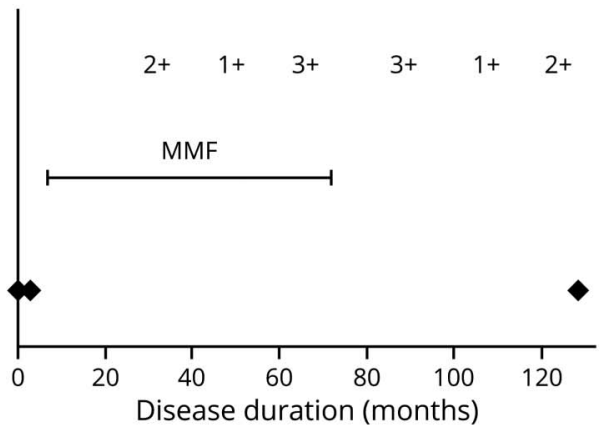

B. Patient 2

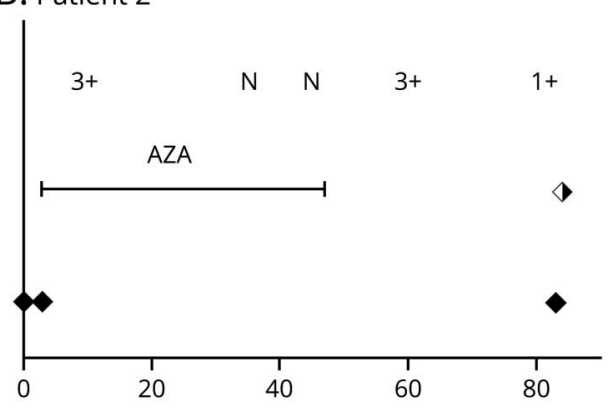

D. Patient 8

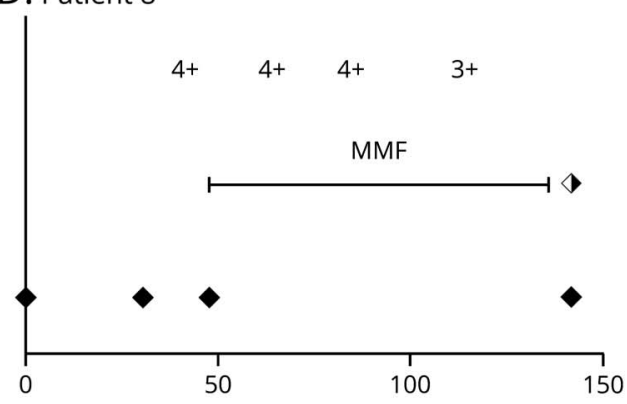

F. Patient 15

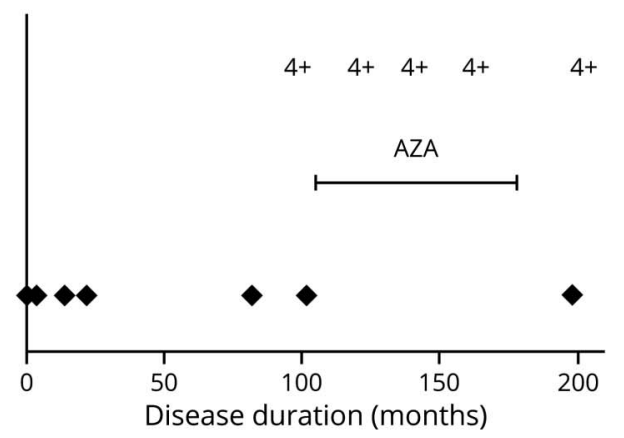

N, AQP4 antibody negative, 1-4+ semiquantitative AQP4 antibody positive score. AQP4 = aquaporin-4; AZA = azathioprine; MMF = mycophenolate mofetil.

prevention therapy in seropositive patients with NMOSD, until future studies enable us to determine when and in which patients IST can be safely discontinued and/or until validated biomarkers to predict relapse well in advance are available.

\section{Study Funding}

This work was supported by the National Research Foundation of Korea (Grant No. NRF-2018R1A5A2023127 \& NRF2016R1D1A1A09916480).

\section{Disclosure}

S.-H. Kim received a grant from the National Research Foundation of Korea. H. Jang, N.Y. Park, Y. Kim, S.-Y. Kim,
M.Y. Lee, and J.-W. Hywn report no financial disclosures. H.J. Kim received a grant from the National Research Foundation of Korea; received consultancy/speaker fees from Alexion, Aprilbio, Celltrion, Eisai, Hanall Biopharma, Merck Serono, Novartis, Sanofi Genzyme, Teva-Handok, and Viela Bio; serves on a steering committee for MedImmune/Viela Bio; is a coeditor for the Multiple Sclerosis Journal and an associated editor for the Journal of Clinical Neurology. Go to Neurology. org/NN for full disclosures.

\section{Publication History}

Received by Neurology: Neuroimmunology \& Neuroinflammation October 5, 2020. Accepted in final form November 12, 2021. 
Appendix Authors

\begin{tabular}{|c|c|c|}
\hline Name & Location & Contribution \\
\hline $\begin{array}{l}\text { Su-Hyun } \\
\text { Kim, MD, } \\
\text { PhD }\end{array}$ & $\begin{array}{l}\text { Research Institute and } \\
\text { Hospital of National } \\
\text { Cancer Center, Korea }\end{array}$ & $\begin{array}{l}\text { Revision of the } \\
\text { manuscript for content, } \\
\text { major role in the } \\
\text { acquisition of data }\end{array}$ \\
\hline $\begin{array}{l}\text { Hyunmin } \\
\text { Jang, RN }\end{array}$ & $\begin{array}{l}\text { Research Institute and } \\
\text { Hospital of National } \\
\text { Cancer Center, Korea }\end{array}$ & $\begin{array}{l}\text { Revision of the manuscript for } \\
\text { content, major role in the } \\
\text { acquisition of data }\end{array}$ \\
\hline $\begin{array}{l}\text { Na Young } \\
\text { Park, RN }\end{array}$ & $\begin{array}{l}\text { Research Institute } \\
\text { and Hospital of } \\
\text { National Cancer } \\
\text { Center, Korea }\end{array}$ & $\begin{array}{l}\text { Revision of the manuscript for } \\
\text { content, major role in the } \\
\text { acquisition of data }\end{array}$ \\
\hline $\begin{array}{l}\text { Yeseul } \\
\text { Kim, MSc }\end{array}$ & $\begin{array}{l}\text { Research Institute and } \\
\text { Hospital of National } \\
\text { Cancer Center, Korea }\end{array}$ & $\begin{array}{l}\text { Revision of the manuscript for } \\
\text { content, major role in the } \\
\text { acquisition of data }\end{array}$ \\
\hline $\begin{array}{l}\text { So-Yeon } \\
\text { Kim, BSc }\end{array}$ & $\begin{array}{l}\text { Research Institute and } \\
\text { Hospital of National } \\
\text { Cancer Center, Korea }\end{array}$ & $\begin{array}{l}\text { Revision of the manuscript } \\
\text { for content, major } \\
\text { role in the acquisition } \\
\text { of data }\end{array}$ \\
\hline $\begin{array}{l}\text { Min } \\
\text { Young } \\
\text { Lee, MD }\end{array}$ & $\begin{array}{l}\text { Research Institute and } \\
\text { Hospital of National } \\
\text { Cancer Center, Korea }\end{array}$ & $\begin{array}{l}\text { Revision of the manuscript } \\
\text { for content, major } \\
\text { role in the acquisition } \\
\text { of data }\end{array}$ \\
\hline $\begin{array}{l}\text { Jae-Won } \\
\text { Hyun, } \\
\text { MD, PhD }\end{array}$ & $\begin{array}{l}\text { Research Institute and } \\
\text { Hospital of National } \\
\text { Cancer Center, Korea }\end{array}$ & $\begin{array}{l}\text { Revision of the manuscript } \\
\text { for content, major role } \\
\text { in the acquisition } \\
\text { of data }\end{array}$ \\
\hline
\end{tabular}

Appendix (continued)

\begin{tabular}{lll}
\hline Name & Location & Contribution \\
\hline Ho Jin & Research Institute and & Drafting/revision of the \\
Kim, MD, & Hospital of National & manuscript for content, major \\
PhD & Cancer Center, Korea & $\begin{array}{l}\text { role in the acquisition of data, } \\
\text { and study concept or design; } \\
\text { Analysis or interpretation of data }\end{array}$ \\
& &
\end{tabular}

\section{References}

1. Wingerchuk DM, Banwell B, Bennett JL, et al. International consensus diagnostic criteria for neuromyelitis optica spectrum disorders. Neurology 2015;85:177-189.

2. Papadopoulos MC, Bennett JL, Verkman AS. Treatment of neuromyelitis optica: state-of-the-art and emerging therapies. Nat Rev Neurol 2014;10:493-506.

3. Kim SH, Jeong IH, Hyun JW, et al. Treatment outcomes with rituximab in 100 patients with neuromyelitis optica: influence of FCGR3A polymorphisms on the therapeutic response to rituximab. JAMA Neurol 2015;72:989-995.

4. Kim Y, Kim G, Kong BS, et al. Large-scale in-house cell-based assay for evaluating the serostatus in patients with neuromyelitis optica spectrum disorder based on new diagnostic criteria. J Clin Neurol 2017;13:175-180.

5. Weinfurtner K, Graves J, Ness J, Krupp L, Milazzo M, Waubant E. Prolonged remission in neuromyelitis optica following cessation of rituximab treatment. J Child Neurol 2015;30:1366-1370.

6. Kim SH, Huh SY, Jang H, et al. Outcome of pregnancies after onset of the neuromyelitis optica spectrum disorder. Eur J Neurol 2020;27:1546-1555.

7. Shosha E. Disease-modifying therapies should be stopped in NMOSD patients in remission-yes. Mult Scler 2019;25:1217-1218.

8. Hua LH, Fan TH, Conway D, Thompson N, Kinzy TG. Discontinuation of diseasemodifying therapy in patients with multiple sclerosis over age 60. Mult Scler 2019;25:699-708

9. Collongues N, Marignier R, Jacob A, et al. Characterization of neuromyelitis optica and neuromyelitis optica spectrum disorder patients with a late onset. Mult Scler 2014;20:1086-1094.

10. Kim SH, Mealy MA, Levy M, et al. Racial differences in neuromyelitis optica spectrum disorder. Neurology 2018;91:e2089-e2099. 


\title{
Neurology \\ Neuroimmunology \& Neuroinflammation
}

\author{
Discontinuation of Immunosuppressive Therapy in Patients With Neuromyelitis Optica \\ Spectrum Disorder With Aquaporin-4 Antibodies \\ Su-Hyun Kim, Hyunmin Jang, Na Young Park, et al. \\ Neurol Neuroimmunol Neuroinflamm 2021;8; \\ DOI 10.1212/NXI.0000000000000947
}

This information is current as of February 23, 2021

\section{Updated Information \& \\ Services}

References

Citations

Subspecialty Collections

Errata

Permissions \& Licensing

Reprints including high resolution figures, can be found at: http://nn.neurology.org/content/8/2/e947.full.html

This article cites 10 articles, 0 of which you can access for free at: http://nn.neurology.org/content/8/2/e947.full.html\#\#ref-list-1

This article has been cited by 1 HighWire-hosted articles: http://nn.neurology.org/content/8/2/e947.full.html\#\#otherarticles

This article, along with others on similar topics, appears in the following collection(s):

Devic's syndrome

http://nn.neurology.org//cgi/collection/devics_syndrome

An erratum has been published regarding this article. Please see next page or:

/content/8/4/e1013.full.pdf

Information about reproducing this article in parts (figures,tables) or in its entirety can be found online at:

http://nn.neurology.org/misc/about.xhtml\#permissions

Information about ordering reprints can be found online:

http://nn.neurology.org/misc/addir.xhtml\#reprintsus

Neurol Neuroimmunol Neuroinflamm is an official journal of the American Academy of Neurology.

Published since April 2014, it is an open-access, online-only, continuous publication journal. Copyright

Copyright $\odot 2021$ The Author(s). Published by Wolters Kluwer Health, Inc. on behalf of the American

Academy of Neurology.. All rights reserved. Online ISSN: 2332-7812.

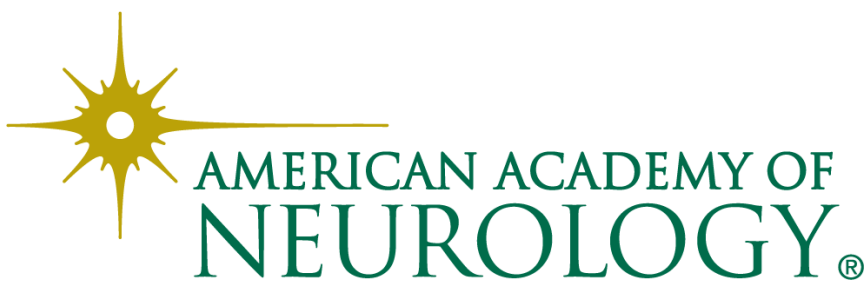




\section{Discontinuation of Immunosuppressive Therapy in Patients With Neuromyelitis Optica Spectrum Disorder With Aquaporin-4}

\section{Antibodies}

Neurol Neuroimmunol Neuroinflamm 2021;8:e1013. doi:10.1212/NXI.0000000000001013

In the article "Discontinuation of Immunosuppressive Therapy in Patients With Neuromyelitis Optica Spectrum Disorder With Aquaporin-4 Antibodies” by S.-H. Kim et al, ${ }^{1}$ Su-Hyun Kim's contributions listed in the appendix should be "Drafting/revision of the manuscript for content, major role in the acquisition of data, study concept or design, and analysis or interpretation of data." The publisher regrets the error.

\section{Reference}

1. Kim S-H, Jang H, Park NY, et al. Discontinuation of immunosuppressive therapy in patients with neuromyelitis optica spectrum disorder with aquaporin-4 antibodies. Neurol Neuroimmunol Neuroinflamm 2021;8:e947. doi: 10.1212/NXI.0000000000000947. 